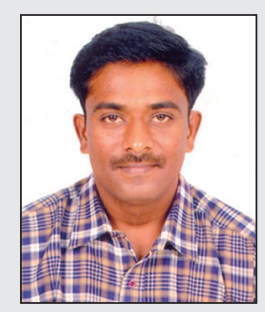

\title{
BIBLIOMETRICS
}

\section{From the Editor's desk....}

Bibliometrics is the statistical analysis of bibliographic data, commonly focusing on citation analysis of research outputs and publications, i.e. how many times research outputs and publications are being cited. Bibliometric analysis is becoming an increasingly important way to measure and assess research impact of individuals, groups of individuals or institutions.

Bibliometrics could help with a number of activities, including:

1. Demonstrating the importance and impact of your own research and/or that of your research group. This can be useful for:

- applying for tenure, promotion or grants

- including bibliometric data on your CV

- demonstrating the value of your research to your institution

- demonstrating return on investment to funding bodies, industry and the general public

2. Identifying areas of research strength and weaknesses. This can be useful for:

- informing future research priorities for an institution

3. Identifying top performing journals in a subject area. This can be useful for:

- deciding where to publish

- learning more about a subject area

- identifying emerging areas of research

4. Identifying top researchers in a subject area. This can be useful for:

- locating potential collaborators or competitors

- learning more about a subject area

- informing the recruitment process

The following table gives more information about some of the main tools used to gather bibliometric data.

\begin{tabular}{|c|c|c|c|}
\hline Tool & About & Access & Metrics available \\
\hline SciVal & $\begin{array}{l}\text { SSciVal is a subscription based research } \\
\text { performance assessment tool which } \\
\text { uses data from Scopus. It allows you to } \\
\text { benchmark individual researchers, groups } \\
\text { of researchers and institutions based on a } \\
\text { variety of bibliometric measures. It holds } \\
\text { information for } 4600 \text { research institutions and } \\
\text { 220countries. }\end{array}$ & Via a subscription. & $\begin{array}{l}\text {-Scholarly Output } \\
\text {-Citation Count } \\
\text {-Citations per Publication } \\
\text {-Cited Publications } \\
\text {-Field-Weighted Citation Impact } \\
\text {-Outputs in Top Percentiles } \\
\text {-H-index } \\
\text {-Journal Count } \\
\text {-Journal Category Count } \\
\text {-Number of Citing Countries } \\
\text {-Collaboration } \\
\text {-Collaboration Impact } \\
\text {-Academic-Corporate } \\
\text { Collaboration } \\
\text {-Academic-Corporate } \\
\text { Collaboration Impact } \\
\text {-Publications in Top } \\
\text { Journal Percentiles }\end{array}$ \\
\hline
\end{tabular}




\section{JOURNAL OF SCIENTIFIC DENTISTRY}

\section{From the Editor's desk....}

\begin{tabular}{|c|c|c|c|}
\hline Scopus & $\begin{array}{l}\text { Scopus is a subscription based citation } \\
\text { database of peer reviewed literature from } \\
\text { more than } 21,000 \text { journals, } 40,000 \text { books, } \\
6.5 \text { million conference papers and } 24 \text { million } \\
\text { patents. The coverage of social sciences } \\
\text { material is broader than Web of Science. At } \\
\text { present, citation data is only available for } \\
\text { papers published from } 1996 \text { onwards. }\end{array}$ & Via a subscription. & $\begin{array}{l}\text {-Scholarly output } \\
\text {-Citation counts } \\
\text {-H-index } \\
\text {-Number of co-authors } \\
\text {-SCImago Journal Rank } \\
\text {-Scopus SNIP }\end{array}$ \\
\hline $\begin{array}{l}\text { Web of } \\
\text { Science }\end{array}$ & $\begin{array}{l}\text { Web of Science is a subscription based } \\
\text { citation database of more than } 12,000 \text { journals } \\
\text { and over } 160,000 \text { conference proceedings. } \\
\text { Coverage includes science, social science and } \\
\text { arts and humanities dating back to } 1900 \text {. }\end{array}$ & Via a subscription. & $\begin{array}{l}\text {-Scholarly output } \\
\text {-Citation counts } \\
\text {-H-index } \\
\text {-Journal impact factor }\end{array}$ \\
\hline $\begin{array}{l}\text { Citation } \\
\text { Reports }\end{array}$ & $\begin{array}{l}\text { Journal Citation Reports is a subscription } \\
\text { based resource which allows you to evaluate } \\
\text { and compare journals using citation data } \\
\text { from over } 11,000 \text { journals. Coverage includes } \\
\text { science, medicine and social sciences dating } \\
\text { back to } 1998 \text {. }\end{array}$ & Via a subscription. & $\begin{array}{l}\text {-Journal impact factor } \\
\text {-Most frequently cited journals in a } \\
\text { field } \\
\text {-Highest impact journals in a field } \\
\text {-Largest journals in a field }\end{array}$ \\
\hline
\end{tabular}

The use of bibliometrics continues to remain controversial due to the following issues and limitations:

1. Citations patterns can differ greatly between disciplines, for example, in certain disciplines research outputs may be cited more frequently than in other disciplines. Therefore it is important to compare researchers, or groups of researchers against those from the same or similar discipline.

2. Some disciplines such as the arts, humanities and social sciences rely less on publishing in journals yet bibliometrics commonly focuses on journal article citations.

3. A paper may be cited in a negative rather than a positive way yet the citation would still be counted.

4. The tools used to gather bibliometric data do not cover all research areas and do not index all publications. Results will vary depending on the tool you use.

5. Manipulation of the system by researchers inappropriately self-citing, citing colleagues, splitting outputs into many articles etc can distort the data. A number of bibliometric tools now allow you to exclude self-citations.

6. Experienced researchers will have an advantage over early career researchers when using certain metrics as they will have produced more outputs. Therefore it is important to compare researchers who are at the same stage of their career.

It is important to remember that bibliometric measures don't necessarily measure the quality of research output and instead focuses on the impact of research, i.e. how often the work is being cited. Just because a research output is highly cited doesn't necessarily mean that the work is of good quality. This is why it is important to use bibliometrics in conjunction with other data such as funding received, number of patents, awards granted and qualitative measures such as peer review.

This above note gives an overview of bibliometrics and today it is been used as an auxillary tool by universities and government agencies to assess the quality of research output

Professor. Saravanakumar. R

Editor - in - Chief

Journal of Scientific Dentistry 